\title{
How does one interpret the Synoptic Gospels' warning passages while affirming the irrevocable nature of salvation?
}

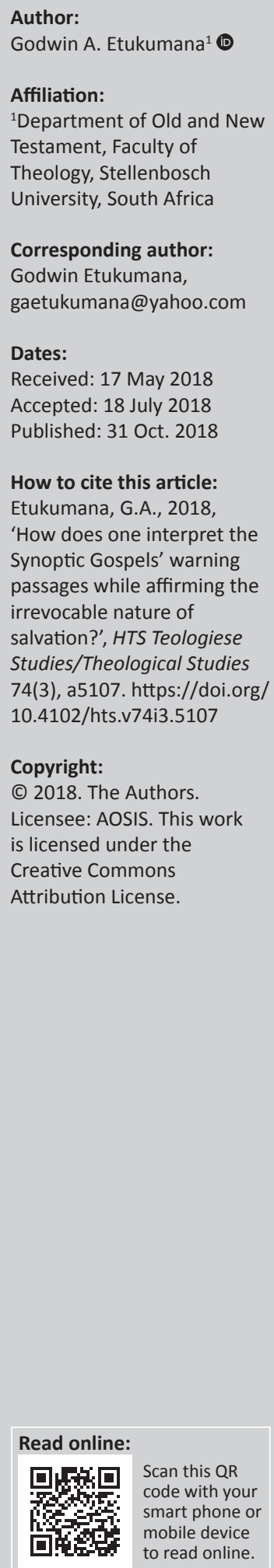

\begin{abstract}
The interpretation of the warning passages in the Synoptic Gospels seems confusing, if not totally unimportant, to many modern biblical interpreters and preachers. Some of these passages have a direct link to the salvation promised to believers in Christ Jesus. The interpretation of such passages in the Synoptic Gospels, while still affirming the irrevocable nature of salvation, becomes problematic. As a result of this, this work sets to develop a methodology for reading such passages with the aim of assuring Christians that their salvation in Christ is an irrevocable gift that God in Christ has provided to those that accepted him as their Saviour.
\end{abstract}

\section{Introduction}

In the New Testament, several warning passages exist and such passages aim at pointing out to believers the need to live in a well-mannered and godly way (Mt 24:12; Col 1:23; Heb 2:1; 3:14; 1 Jn 2:6). Such warning passages are spread all over the Synoptic Gospels (Mt 10:33; 12:31-32; Mk 3:28-30; 8:38; 9:26; 12:8-9; 13:1ff.; Lk 17:22-35). These warning passages are those passages that 'exhort the readers to persevere in honoring God's message via the Son, lest some sort of divine judgment befall them' (Bateman 2007:28). Interpretation of the warning passages in the Synoptic Gospels is one of the problems that have currently faced Synoptic scholarship. Passages that are seemingly controversial present difficulties for one to interpret to suit the need and purpose of the community in which the text originated during the 1st century BCE. The understanding of the community in which the text originated plays a very important role in interpreting the text. The life of the community and the sociological behaviour of the people that made up the community influence the interpretative framework to be adopted in the interpretation of such documents. It is believed that such sociological behaviour might perhaps have been controlled by the social norms originating from the social domain of the community. Communal ethos became one of the principal factors that determined how people lived and behaved as they interacted with one another in their community. Bringing all these conditions into a given text enables an interpreter to view a given text as something that depicts the day-to-day interaction of the people who lived and walked in that community.

The same notion could also be applicable in the study of the New Testament, especially the Synoptic Gospels. The authors of the Gospels were human beings who lived and walked the streets of their various communities, and these daily actions influenced and affected their mode of behaviour and sense of perceptions. Their behaviours during day-to-day activities were further shaped and controlled by their community in the form of communal ethos (Hays 2006:13-15). This ethos was a critical sign that fashioned the identity of the early Jesus community. Keeping the communal ethos by the members of such a community invariably produced a communal identity that showcased a specific lifestyle that was inculcated and approved by the community (Hays 2006:15). The intention of this article is to generate a method for interpreting some of the warning passages in the Synoptic Gospels while affirming the irrevocable nature of salvation enshrined within these texts. This article will not only generate such a model or method but will test the method in some key passages that have relevance to the working topic of the article. The reason for doing this is to know the reason behind the emergence of such warning passages, irrespective of the assurance of salvation promised within the text of the Synoptic Gospels. ${ }^{1}$ The question of how to interpret these passages becomes the most important part of this and why such passages emerged from the community who claimed to have seen the Saviour of the world raises a great

1.This article will consider at least one of these warning passages in each of the Synoptic Gospels. This consideration will be based on methodology that will be developed later as this article progresses. 
concern for this article. As noted by Thomas R. Schreiner (1998:31), '[o]ne of the most difficult issues in reading the scriptures is explaining the tension between warning passages and texts that promise assurance'. In order to carry out the task of explaining this tension, there is a need for formulating a method of approaching the passages to be considered. Communal sociology is made up of the teaching of ecclesia that was embedded within their community practice and ethos. The term ecclesia in this context is implicatively sectarian and cultic as depicted in the New Testament ecclesiastical community (Hanges 2012:40-49). The concept of ecclesia is derived from the ancient Greek. The term was used in reference to those who were elected to make laws on behalf of the Athenian citizens. The concept of the New Testament's ecclesia, though derived from the ancient Greek, nonetheless expresses a deeper connotation than that of the Athenians. Rudolph Sohm's understanding of New Testament ecclesia provides insights into how the early Christian community defined itself and its mission in the world. ${ }^{2}$ The early Christian community used the words and actions to define their separation from the other sects or religious groups that were around at that time. Ecclesia actually defined their identity and tied them and their community to the person of Christ. This sociological perspective on early Christianity will form the basis on which some of the passages will be considered and read.

The warning passages should be read as sectarian texts as that of the Essene community, who believed that they were the possessors of the promise of salvation, but in order to attain the full grasp of it there were certain requirements that its members must adhere to. The Essenic community believed and practised discipline that would help their community foster and project their beliefs and identity to the next generation (Lim 2009).

The sociological characteristics of the ecclesia are embedded within the framework of its beliefs as a messianic community whose identity had to be fostered based on the principle and the ethos of Jesus (Steyn 2006:157-158). Their practices were determined by the ethical conduct that guided them as a people of faith with the specific destiny of changing humanity. The belief of the community was that anyone who had been accepted into the community had a duty to live in line with the communal ethos, which according to Sohm (in Nardoni 1992:647-648) was solely directed by the word of God and the leadership of the Holy Spirit. Ecclesiastical sociology demands that every member of the community keep to the tenets and rules that guide the community. It was the communal ethos that was formulated on the basis of the sociology of ecclesia that dictated the lifestyle of the members within early Christianity (Combrink 2006:23-33). Therefore, the sociology of the early Christian should be the emblem on which interpretation of their document rests.

2. Rudolph Sohm in his thesis published as Ecclesiastical Law in 1892 asserts that the early church received its authority not from any human being but from the word of God and there was no imposition by any individual or group of people as to its activity except as directed by the charisma of the Holy Spirit. This invites the idea that the church was not an exact semblance of the Athenian ecclesia, who were that the church was not an exact semblance of the Athenian eccles
basically directed by the Athenian constitution (see Nardoni 1992).
This emblem of the early community was encapsulated or wrapped in those tenets that held the fibre of their community together.

The key belief of the community was that every member of the community was expected to suffer for the sake of their beliefs (Madsen 2007:46-58). Therefore, suffering became one of the mandated parameters through which the disciples interpreted and claimed the promise of the scripture. ${ }^{3}$ Suffering, perseverance and theologia crucis or staurology became the premise upon which the faith and the symbol of the community relied. Reading the Synoptic Gospels, it is easy to decode from its content the undeniable power of the suffering, perseverance and theologia crucis in their work. These three ecclesial sociological beliefs spanned the entire life of the early Christian community and patterned their ethical conduct and behaviour. Basing the ecclesia sociology or the sociology of early Christianity on the doctrines of suffering, the perseverance and the cross enable one to read what the community believed in terms of their relationship to Christ and the outside world. The trio of sociological principles became notable for testing who was a member of the community and who was not.

\section{Suffering and its role in early ecclesia}

Reading the warning passages in the Gospels in light of the communal sociology of suffering as a social benefit that belonged to all the members of the community provides an ambience through which a reader sees the place of suffering as a means through which the adherers could possess their salvation. Suffering was a means by which Jesus accomplished his mission on Earth and his disciples were obliged to follow in his footsteps (Mt 17:12, 22-23; 20:17-19; Mk 8:31; 9:31; 10:33-34; 14:34; Lk 9:22; 22:15, 44; 24:46) (see Hartog 2016). As a result, to all the followers of Jesus, suffering became a means through which they would see the kingdom of God. The Synoptic Gospel writers and the early Christian community believed that suffering for the sake of Christ was a means of entering the kingdom of God (Gärtner 1978: 723-725). This belief contradicts that of the Old Testament that suffering is a result of one's sin (Ex 21:24; Subramanian 2007:70); rather, in the New Testament it is clearly shown that sometimes suffering is from the enemy (Mt 13:13; Mk 4:17; 13:9) and that it is the duty of the new community or ecclesia to confront him (Neubauer 2012:29-30). The new community's belief in suffering provided a pathway through which the ecclesia interpreted the qualities of those who would inevitably inherit the kingdom of God (Mt 5:10-12; Lk 6: 20-26). The Synoptic Gospel writers saw Christians' participation in suffering as the fulfilment of scripture (Subramanian 2007:125). Debashis Guha's (2007) inquiry into the essence of the early Christian's participation in pain and suffering draws the following conclusion:

3.The term 'suffering' is used by New Testament writers in many ways. The word 'suffering' is derived from that root word $\pi \alpha \dot{\sigma} \sigma \chi \omega$, with the possible meaning 'to 'suffering' is derived from that root word $\pi \alpha \sigma \alpha \chi \omega$, with the possible meaning 'to
suffer'. It often refers to sacrificial suffering, 'however, the word-group serves to suffer'. It often refers to sacrificial suffering, 'however, the word-group serves
describe the suffering of Christ and that of his disciples'; see Gärtner (1978:723). 
The essence of the Christian response to suffering is the realisation of God as Father and it comes out in Matthew's Sermon in [sic] the Mount. It makes entirely clear that a disciple's response to suffering is practical and active because it is laid in the pattern of Christ's own life as a testimony to the fact that extreme suffering may be overlooked at the face of the sustained relationship of child and father. It is due to this that extreme physical agony in crucification [sic] may give way to deep love for the father. (pp. 114-115)

Guha's idea of suffering, though philosophical, explains the reason for suffering in the New Testament. The New Testament community believed that the suffering of believers sustained their relationship with God the Father and guaranteed their place in the kingdom of God.

\section{Perseverance and the salvation of ecclesia}

While the disciples or the early Christian community believed that suffering was a means through which they would conquer the evil world and obtain the kingdom (Mt 5:3; 5:10; 19:12; Mk 10:23-25; Lk 6:20; 18:29), the perseverance in suffering became the hallmark of this faith and belief (Marshall 1969:55-73). The early Christian community developed the doctrine of perseverance (Mt 10:22) as a means of sustainability and encouragement to the newly founded community of faith to continue their suffering in Christ. Perseverance therefore becomes the anchor that holds the early Christian ecclesia and the determining factor of who was a member of their community, especially when faced with persecution (Mk 13:13). Perseverance amidst persecution and suffering was regarded as genuine and one of the key possessions of the ecclesia (Lk 21:18f). The tenacity to withstand impediments posed by the devil and his kingdom was a great mark of anyone who was willing to be to be saved (Marshall 1969:75). The temptation of Jesus in the Gospels signals a struggle between the kingdom of God and that of Satan for their survival (Mt 4:1ff. Lk 4:1ff.). Despite the temptation that Jesus went through, he was able to overcome, thereby giving assurance to those who would follow in his footsteps (Lk 9:23).

The ability of Jesus to persevere in order to overcome the devil was a clear sign that the kingdom of God is ready to exist among mortals. However, the New Testament concept of the kingdom of God and its derivation is absent in the Old Testament. According to I. H. Marshall (1969):

$[t]$ he kingdom of God is a term which refers both to the saving act of God in exercising His kingship over the world in order that He might be ruler of a community redeemed from the power of Satan and to the realm or community which set up as a result of God's action. (p. 52)

Thomas R. Schreiner and Ardel B. Caneday believe that the process of perseverance is embroidered within the biblical context of the conditional promise and conditional warning texts. In other words, God's saving event and damnation 'is contingent upon' one's ability to persevere. ${ }^{4}$ The view of perseverance in this context is typified by the divine power given to believers to hold on until their salvation is consummated at the Parousia.

In order to define the meaning of the warning passages in the Synoptic Gospels, the early Christian community was able to give their meaning to the actions and words of Jesus of Nazareth, their Master and Saviour. These actions and words expressed their functionality through the finished work of Jesus on the cross - salvation as understood by the authors of the Gospels is based on the finished work of Jesus on the cross. The same notion was held by the early Jesus community and provided a warranty to the early Christian community to hold on to the power of the cross as a major symbol of their redemption. The finished work of Jesus Christ on the cross is the modus operandi that the early church and their disciples believed as a means of their salvation (Morris 1999:37). The writers of the Gospels believe that salvation is based on the coming of Jesus and the action that he wrought on the cross. Salvation in this case includes both the Old Testament and the New Testament concepts (Lk 2:28-31). While the Old Testament's emphasis was on the present world, the New Testament differs and projects the kingdom to be the event that is beginning in this world and culminating in the eschatological kingdom of God. The question that the disciples of Jesus posed to him significantly proved that the disciples still upheld the belief that the kingdom of God was within the reach of earthly political kingdoms (Ac 1:6). If we hold this notion in mind, the warning passages as pertaining to salvation will not be a problem when interpreting them. Thus,

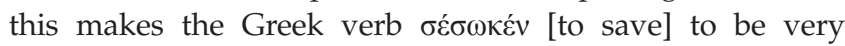
important (Mt 9:22; Mk 5:34; 10:52; Lk 7:50; 8:48; 17:19; 18:42). The same word is translated by KJV as 'made whole', a word that conceptually embodied both physical and spiritual salvation - in other words, both the earthly and heavenly. ${ }^{5}$

The necessity of obtaining salvation has in recent times been subjected to scholarly scrutiny. The role of work in obtaining salvation in the Synoptic Gospels has received a new face contrary to the hermeneutic interpretation of the Reformation fathers. ${ }^{6}$ Work after salvation is the basic tenet of the Christian faith, which is illustrated through the symbolism of the cross. The irrevocable nature of Christian salvation is found on focusing through faith on the cross of Christ as we persevere in our suffering.

\footnotetext{
4 . Ben Holloway (2017). The proponents of this view do not state clearly the ground of their argument. Their view sounds as if the believers' salvation is directly of their argument. Their view sounds as if the believers' salvation is directly
proportional to their ability to persevere. To figure out the meaning of the statement
of Jesus in Matthew 10:22 needs a special tool of exegesis other than what has been of Jesus in Matthew 10:22 needs a special tool of exegesis other than what has been
invented up to the present. Our view in this article is that the New Testament concept of salvation and its meanings must be given premium in interpreting a text of this nature.

5.This embodiment of total redemption makes up the hermeneutical trajectory through which the African scholars read their context of salvation. The liberation of the sufferer from the pains and whatever ailment that he or she suffered indicates that such person was delivered and offered salvation (see Van Eck 2006).

6.The argument against the doctrine of salvation by grace alone has been recently disputed by the publication of Alan Stanley (2010). According to Alan P. Stanley, he argues that Jesus of the New Testament did not preach that the salvation is absolutely free, but for one to have his/her salvation there is tendency of applying absolutely free, but for one to have his/her salvation there is tendency of applying
work. Based on his interpretative schema, work and salvation are inextricably linked work. Based on his interpretative schema, work and salvation are inextricably linked
(see Stanley 2010:515-337).
} 


\section{The theologia crucis}

The communal faith was radiant and shaped by the doctrine of the cross (Morris 1999:25-27). ${ }^{7}$ The cross as a symbol of death and the resurrection of Jesus was a foundation through which the early Jesus ecclesia anchored their indefatigable faith. In the Synoptic Gospels heavy emphasis is laid on the cross of Christ as a means through which the salvation of the early community was attained (Mt 10:38). The cross was seen not only as the symbol that brought salvation but also as a symbol of suffering and shame. The ability for one to focus on the finished work of Jesus on the cross became a means of inauguration into the new covenant through the blood of Jesus (Lk 22:20). It is on the basis of this covenant that the early Jesus community interpreted their dealings with Jesus as a fulfilment of the Old Testament covenant that YHWH promised the household of Israel (Chilton 1997:72). The early disciples made up the covenant community, which can be termed as the earthly kingdom of God. The prerequisite for entering the kingdom is through believing in the finished work of Jesus on the cross and the power of his resurrection. One's inability to endure the cross was a denial of faith. The cross was both a rhetorical and symbolic expression of one's position in the salvific economy of the new covenant in Christ. Everyone was expected to carry his or her cross consistently till death as a clear sign that the person had believed and stood with him till the end. ${ }^{8}$

\section{The irrevocable salvation and the warning passages}

We started this article by trying to indicate how the warning passages were read by the early Jesus community; there is need to carefully examine texts that have relevance to the warnings. A few of these warning passages will give us insight as to how the early Jesus community read and believed those texts. Did the early Jesus community believe that one could easily lose his or her salvation? The following texts will be read based on the role set by the early Jesus community, who were acquainted with Jesus and his works.

\section{Absolute allegiance in Matthew 10:32-33}

The context of Matthew 10:32-33 is that of discipleship and what is expected of a disciple and a would-be-disciple. One such demand from the disciples was undivided and total allegiance. This is confirmed by the statement of Jesus to his disciples in the text:

Therefore everyone who acknowledges me before people, I also will acknowledge him before my Father who is in heaven. But whoever denies me before people, I also will deny him before my Father who is in heaven. ${ }^{9}$

7.The use of cross in this article is a metaphor for the death of Jesus and his resurrection and also portrays as a symbol of suffering as in Luke 9:22-23.

8.During the Reformation period, Reformation fathers the likes of Martin Luther and John Calvin believed in this strongly as a means through which believers have to show their faith (Zachman 1993:57).

9.This quotation of the Bible is from Lexham English Bible. See Harris et al. (2012).
The warning in this Matthean text is obvious and pivoted on the declaration as a means through which one would be saved. This action could be linked with covenant declarations in the ancient Near East in which a person (vassal) must declare his total and unadulterated alliance to the suzerain (Harrison 1985:476-477). It was a duty of the suzerain to protect the vassal who publicly declared unadulterated alliance to him. This assertion is conspicuous through the use

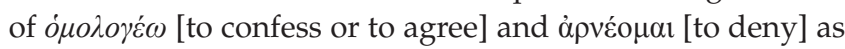
antithesis in the text. Did Jesus actually make reference to the use of these two words as used by the author of Maccabees? The former is used in 4 Maccabees 9:16 to mean 'confession' while the latter is used in 4 Maccabees 10:15 to depict an action that one is forbidden as a result of a bond existing within the brotherhood. To deny this bond means denying one's membership. This text in Maccabee (4 Macc 10:15) is worth citing here:

No, by the blessed death of my brothers, by the eternal destruction of the tyrant, and by the everlasting life of the pious, I will not renounce our noble brotherhood.

The two verbs are in contrast to each other but are crucial in understanding the sociological configuration of the ancient world. Viewing the two verbs 'to confess' and 'to deny' in terms of an action that both represent, 'denial' and 'public declaration for' cannot go together. Either one 'denies' or 'publicly declares in favour of' what he or she believes to be the truth and trustworthy. The action of the disciples within the text informs a reader whether such a disciple is of Christ or not. The usage of these two verbs ('to confess' and 'to deny'), according to I. H. Marshall (1969:62), indicates that Jesus was addressing an audience that was made up of believers and non-believers and he (Marshall) therefore refers to this audience as a mixed community. While the interpretation of mixed community as postulated by I. Howard Marshall and C. Adrian Thomas might not be the necessary reason for this text (see Marshall 1969:62-67; Thomas 2008:15), human frailty and ability to derail from the truth is possible in the context of this text. However, Jesus at this juncture was demanding a total and an unadulterated obedience from his new community. ${ }^{10}$

There are two considerations in interpreting the above passage. Firstly, the passage denotes suffering, perseverance and taking up the cross till death by any would-be disciples. By implication, a disciple who does not give up in the midst of suffering and persecution remains a faithful witness to the cross of Christ. Secondly, the passage demands total allegiance from the disciples. It is a principle that all the disciples of Christ must abide with and without which it is difficult to be called a disciple of Christ.

\section{Mark 13 and the need to be watchful}

Mark 13 alongside Matthew 24 and Luke 21 formed what John Calvin (1979:114-115) calls the 'eschatological' block of 10.Vincent Taylor, Mark, 205, citing Marshal Kept by the Power of God, 58. 
the Synoptic Gospels or what Mary Ann Beavis calls 'little apocalyptic' ${ }^{11}$ The setting of Mark 13:1-37, according to Donald E. Hartley (2006:234), is based on seeing on the part of the disciples. Even though Timothy J. Geddert (1989) is of the opinion that the chapter deals with eschatological discourse, he moves on to adduce that:

[t]he obvious implication is that Mark's central concern is neither Christology nor eschatology. Discipleship as it is tied to passion theology forms Mark's 'centre of gravity', in the Gospel as a whole and in Mark 13. (p. 196)

This implies that the disciples were to pattern their lifestyles based on their master's passion event.

Again, the context of Mark 13 defies the mixed audience interpretation of Marshall and Thomas, who postulate that Mark 13 is one of the texts that directly implicates a mixed community (Schreiner 2010:81). However, Thomas Schreiner (2010:81) is of the opinion that the warnings in the Synoptic Gospels are meant only for the new covenant community, as a means of keeping them from falling from the salvific grace. Jesus in this text is responding to the question of the sign of his second coming or what might be called 'the eschatological discourse' (Mk 13:4; Schreiner 2010:86). The author's use of ¿ $\delta$ io $\varsigma$ [in private] (Mk 13:3) nudges us to see the discourse as private and meant only for the disciples who gave all to follow Jesus; Mark also specifies that not all the disciples were with Jesus but only the inner caucus of Jesus' disciples. The names of the disciples are mentioned by Mark to inform the reader of the nature of the community that the words of Jesus were meant for, contrary to the other evangelists, who just use the word 'disciples' (Calvin 1979:121). The Markan narrative shows that the named disciples were the first quaternion of the Twelve' (see Jamieson, Fausset \& Brown 1997:86). The author's narrative provides no room for a mixed community but only for those who are truly the disciples of Jesus. These disciples depict what Suzanne Watts Henderson (2006) describes as those who are willing and ready to participate in fulfilling the mission of Jesus on Earth when she says:

\footnotetext{
.. Mark portrays faithful discipleship not in terms of correct Christological confession but rather as active participation in Jesus' Christological purpose. In turn, then, the disciples' ineptitude must be assessed not strictly according to their beliefs about Jesus' messiahship, but more broadly in terms of their own participation in his gospel mission. (p. 250)
}

The ultimate duty of these disciples in the Markan text is to make sure that the good news is preached to the entire world (Mk 13:10; Beavis 2011:205). The very ones who will endure the suffering to the end are those who will be saved (v. 13; Schreiner 2010:86). The chapter further enumerates what awaits the disciples of Jesus as they witness in the evil world. They are those who will face tribulation (v. 19), those whom the false Christs will confront and will do everything to lead

11.Beavis (2011:188). Before the writing of Mary Ann Beavis's work Timothy. Geddert (1989) had already published a full monograph on eschatologica discourse on Mark 13 in her work: Watchwords: Mark 13 in Markan Eschatology: Sheffield Academic Press, Sheffield. them astray (vv. 21-22). The culmination of this warning is found in verse 23. This verse marks the end of the first eschatological discourse and warnings (13:5-23). John Painter (1997:170) alludes that:

[t]his whole section (13.5-23) concludes as it began with a call to 'Watch out', here without any specific reference but covering all the warnings given to this point, with the assurance 'I have foretold all things to you'. The motto is 'forewarned is forearmed' as long as you 'watch out'. (p. 170)

Calvin (1979:120-121) believes that the warning itself proves that provision had already been made for the disciples so that they would not want for anything.

The key word in the discourse is $\gamma \rho \eta \gamma o \rho \varepsilon ́ \omega$ [watch] (KJV, RSV and NIV), c (NABS) and its reiteration signifies the importance of the discourse to Jesus' community. The text, according to Calvin (1979:156-159), does not project the possibility of the elect falling away from grace; rather it informs the need for them to recognise the grace that is available to them. Therefore this 'salutary warning' in the text, according to Calvin, is synonymous with grace (Calvin 1979:157-158). The warning is not to indicate that the community can fall from salvation but is a means of grace to imitate the master. Imitation of Christ (imitatio Christi) becomes the hallmark through which the new community builds their ethical norms.

\section{The warning and the salvation of the disciples in Luke 17:22-35}

There is a correlation between Mark 13 and Luke 17:22-37 in the context of the Synoptic Gospels' eschatology. The Markan text expects the eschatological coming of Jesus or the Messiah, while the Lukan eschatology expects the coming of the Son of Man (Nolland 1989:856). What is quite interesting is how Luke narrates the version of his discourse and injects some key Old Testament figures, such as Noah and Lot, who escaped destruction during their time. Again the focus of the story is on the disciples (Nolland 1989:863). This implies that the disciples are the main audience in the story. The eschatological depiction in Luke 17:26-27 compares the coming of the Son of Man to the time of Noah and asserts that Noah's contemporaries lived licentious lifestyles until they were overtaken by the flood (Knight 1998:126). We are told by the author of the Book of Genesis that Noah found favour with God (Gn 6:8). As Noah received the message to build an ark during his time, so did the disciples of Jesus in their time. According to John Calvin (1979:157, 158), the warning is flavoured with grace that will make the disciples persevere till the end. The same grace was given to Lot and his family, but sadly the wife of Lot could not make it to the end. The mentioning of Lot's wife in this eschatological discourse is mind probing. Does Jesus mean that there is a tendency for the elect to look back and perish or does Jesus use it as a means of teaching his disciples the need to be prepared at all times? Possessions and desire for earthly things were what caught the attention of Lot's wife in Genesis 19:26. 
The allusion to Genesis 19:26 is crucial, seeing that in the parable of the prodigal son (15:11-32), the parable of the unrighteous steward (16:1-18) and the parable of the rich man and Lazarus (19:19-31), Jesus here warns his disciples to be careful not to be easily carried away by the desire for wealth. Lot's wife in the Lukan eschatological context represents human tendency of craving for those things that have no eternal value. Even though salvation is free, the preceding verse (v.31) is a warning to the disciples. The verse also depicts the state of readiness of the disciples of Christ. Verse 32, where allusion is made to Lot's wife, becomes a pivot upon which verses 31 and 33 rotate. According to Nolland (1989), Lot's wife:

was part of the group to be rescued, but fails to put the requisite distance between herself and the city and is finally engulfed by the judgment that falls upon the city. (p. 861)

The verse is a salient warning to the followers of Jesus to be always ready for the coming of their Lord, as reiterated in verse 33 (see also 9:23-27). The cross becomes a focal point not only as a means for imitation of Christ but a means of doing his will (Cunningham 1997:25).

The imagery of the disappearance of people, body and eagle (Matthew 24:28) entails the final gathering of the faithful ones, and assurance of eternal bliss to the faithful disciple that wherever their master is, there all of them will be also (Nolland 1989:863). ${ }^{12}$ The appearance of the Lord means the gathering of his servants who persevered in suffering and trusted in his grace for the purpose of fulfilling the mission he entrusted into their hands.

\section{Conclusion}

Having seen the nature of human frailty and the tendency for humans to be led astray, Jesus decided to provide the necessary grace in the form of a warning to his community. The salvation of the community and their lifestyle were inextricably linked. Salvation was evident in the lifestyle of the ecclesial community and thus helped them to be ever ready for the sudden coming of their Master. The lifestyle of Jesus' community enabled them to persevere even through suffering in the belief that the cross alone was the only symbol of their salvation. While the disciples believe they are enjoying salvation, there is a need for them to be careful so as not to be carried away by false teachers who parade themselves as Christs (Mt 24:24; Mk 13:22). While one's belief determines one's destiny, sometimes it is difficult to identify those who are actually believers in Christ as their Lord and Saviour. The warnings in the Synoptic Gospels indicate a means of grace that would enable the disciples to imitate the selfless sacrifice of Christ.

The ecclesia as a new covenant community within the Synoptic Gospels informs any reader that the grace that appeared in Jesus supremely exceeds that of the Old Testament covenant (Chilton 1997:72-73). The authors of gathering of the followers of Jesus. the Synoptic Gospels (Matthew, Mark and Luke) believe that the coming of Jesus into the world is an authenticated expression of God's grace to those who believe in him (Mt 8:13-17; 12:17-22; Mk 7:32-35; Lk 2:40; 7:26). Our salvation is irrevocable, but there is a need for Christians to demonstrate this irrevocability of their salvation with good works and alertness while waiting for Jesus' coming. The warnings should act as a means of grace to those who fulfil the early Christian community's ethos of suffering, perseverance and unrelenting faith in the power of the cross and the resurrection of Christ as the church waits for his second coming.

\section{Acknowledgements Competing interests}

The author declares that he or she has no financial or personal relationships which may have inappropriately influenced him or her in writing this article.

\section{References}

Bateman, H.W. IV, 2007, 'Introducing the warning passages in Hebrews: A contextual orientation', in H.W. Bateman IV (ed.), Four views on the warning passages in Hebrews, pp. 23-85, Academic \& Professional, Kregel.

Beavis, M.A., 2011, Mark: Paideia Commentary on the New Testament, Baker Academic, Grand Rapids, MI.

Calvin, J., 1979, Harmony of the evangelists: Matthew, Mark, and Luke, vol. 3, transl., W. Pringle, Baker Book, Grand Rapids, MI.

Chilton, B., 1997, 'Ideological diets in a feast of meanings', in B. Chilton \& C.A. Evans (eds.), Jesus in context: Temple, purity, and restoration, pp. 59-90, Brill, Leiden.

Combrink, H.J.B., 2006, 'The challenge of overflowing righteousness: To learn to live the story of the gospel of Matthew', in J.G. van der Watt (ed.), Identity, ethics, and ethos in the New Testament, pp. 23-48, Walter de Gruyter GmbH, Berlin.

Cunningham, S., 1997, 'Through many tribulation': The theology of persecution in Luke-Acts, Sheffield Academic Press, Sheffield.

Gärtner, B., 1978, 'Suffering', in New International Dictionary of New Testament Theology, vol. 3, pp. 719-726, Zondervan, Grand Rapids, MI.

Geddert, T.J., 1989, Watchwords: Mark 13 in Markan Eschatology, Sheffield Academic Press, Sheffield.

Guha, D., 2007, An inquiry into the cases of pain and suffering, Concept Publishing, New Delhi.

Hanges, J.C.P., 2012, Founder of churches: A study in light of the evidence for the role of 'Founder-Figures' in the Hellenistic-Roman period, pp. 40-49, Mohr Siebeck, Tübingen.
Tün

Harris, W.H., III, Ritzema, E., Brannan, R., Mangum, D., Dunham, J., Reimer, J.A. et al. (eds.), 2012, The Lexham English Bible (Mt 10:32-33), Lexham Press, Bellingham.

Harrison, R.K., 1985, Introduction to the Old Testament, Wm. B Eerdmans, Grand Rapids, MI.

Hartley, D.E., 2006, The wisdom background and parabolic implications of Isaiah 6 : 9-10 in the Synoptics, Peter Lang, New York.

Hartog, P.A., 2016, 'Suffering', in J.D. Barry, D. Bomar, D.R. Brown, R. Klippenstein, D. Mangum, C. Sinclair Wolcott, et al. (eds.), The Lexham Bible Dictionary, Lexham Press, Bellingham.

Hays, R.B., 2006, 'Mapping the field: Approaches to New Testament', in J.G. van der Watt (ed.), Identity, ethics, and ethos in the New Testament, pp. 3-19, Walter de Gruyter GmbH, Berlin.

Henderson, S.W., 2006, Christology and discipleship in the Gospel of Mark, Cambridge University Press, Cambridge.

Holloway, B., 2017, 'Review: The race set before us: A biblical theology of perseverance \& assurance by Thomas Schreiner and Ardel Caneday', The Holloway Quarterly, viewed 19 May 2017, from http://www.hollowayquarterly.com/2017/03/reviewrace-set-before-us-biblical.html

Jamieson, R., Fausset, A.R. \& Brown, D., 1997, Commentary critical and explanatory on the whole Bible, vol. 2, Logos Inc., Oak Harbor, WA.

Knight, J., 1998, Luke's Gospel, Routledge, London.

Lim, T.H., 2009, 'Towards a description of the sectarian matrix', in F.G. Martínez (ed.), Echoes from the caves: Qumran and the New Testament, pp. 7-37, Brill, Leiden.

Madsen, A.M., 2007, The theology of the cross in historical perspective, Wipf and Stock publications, Eugene, OR. 
Marshall, I.H., 1969, Kept by the power of God: A study of perseverance and falling away, Bethany Fellowship Inc., Minneapolis, MN.

Morris, L., 1999. The cross in the New Testament, W. B. Eerdmans Publishers, Grand Rapids, MI.

Nardoni, E., 1992, 'Charism in the early church since Rudolph Sohm: An ecumenical challenge', Theological Studies 53, 646-667.

Neubauer, J., 2012, Differences between John and the Synoptic Gospels, Grieving Teens Publishing, CA.

Nolland, J., 1989, Luke 9:21-18:34: Word Biblical Commentary 35b, Thomas Nelson Publishers, Nashville, TN.

Painter, J., 1997, Mark's Gospel worlds in conflict, Routledge, London.

Schreiner, T.R., 1998, 'Perseverance and assurance: A survey and a proposal', The Journal of Southern Baptist Theology 2/1, 32-62.

Schreiner, T.R., 2010, Run to win the prize: Perseverance in the New Testament Crossway, IL.
Stanley, A.P., 2010, Did Jesus teach salvation by works? The role of works in salvation in the Synoptic Gospels, The Evangelical Theological Society Monograph Series 4 Pickwick Publishers, Eugene, OR.

Steyn, G.J., 2006, 'Driven by conviction and attitude! Ethics in the acts of the apostles', in J.G. van der Watt (ed.), Identity, ethics, and ethos in the New Testament, pp. 135-163, Walter de Gruyter GmbH, Berlin.

Subramanian, J.S., 2007. The Synoptic Gospels and the Psalms as prophecy, T \& T Clark, London.

Thomas, C.A., 2008, A case for mixed-audience with reference to the warning passages in the Book of Hebrews, Peter Lang, Bern.

van Eck, E., 2006, 'The word is life: African theology as biblical and contextual theology', HTS Teologiese Studies/Theological Studies 62(2), 694. https://doi. org/10.4102/hts.v62i2.359

Zachman, R.C., 1993, The Assurance of faith: Conscience in the theology of Martin Luther and John Calvin, Fortress Press, Minneapolis, MN. 